\title{
Intellectual Property Protection and Technology Transfer Evidence from US Multinationals
}

\author{
Sunil Kanwar ${ }^{*}$ \\ Delhi School of Economics \\ and \\ Department of Economics, UC San Diego
}

Discussion Paper 2007-05, Department of Economics, University of California San Diego, July 2007. 


\title{
Intellectual Property Protection and Technology Transfer Evidence from US Multinationals
}

\author{
Sunil Kanwar* \\ Delhi School of Economics \\ and \\ Department of Economics, UC San Diego
}

\begin{abstract}
This paper investigates whether, in what direction, and to what extent one mode of technology transfer is influenced by the strength of intellectual property protection that host nations provide. Using data spanning the period 1977-1999, we find little support for the claim that strengthening intellectual property rights will have any sizable effect on the magnitude of overseas r\&d investment by (US) multinationals. Any semblance of a positive relationship between these two variables vanishes the moment we introduce country fixed effects and time fixed effects into the regressions. One implication of our results is, that ceteris paribus, stronger intellectual property rights in the developing countries pursuant to the TRIPs agreement may not have any significant influence on technology transfer into these countries via overseas r\&d.
\end{abstract}

JEL Codes: O34, O31

Keywords: intellectual property, technology transfer, overseas r\&d

* Correspondence address: Department of Economics, Delhi School of Economics, University of Delhi, Delhi 110007, India; sunil_kanwar@econdse.org 


\section{Intellectual Property Protection and Technology Transfer Evidence from US Multinationals}

\section{The Larger Picture}

Today innovation or technological change is seen as a prime motive force behind economic growth. ${ }^{1}$ The innovation in a given country may be conducted by domestic entities and/or foreign entities resident there. For many countries, the latter or the research and development activities of multinationals may be a notable source of both technology transfer as well as technology diffusion. Thus, Harrison (1994) avers that new technology may not always be available on the market via licensing arrangements; so that joint ventures with innovating multinationals may be the best means of learning new technology. Further, such tie-ups with foreign innovating firms may be the best source of certain forms of managerial human capital formation, with possible spillovers into the domestic economy. While this may be more likely in the case of developing countries (which have been net technology-importers), it may be true of developed countries as well (insofar as technical and scientific manpower moves between firms in developed countries too). To the extent that such spillovers are a more important mode of technology transfer and diffusion for developing countries, it is a mode these countries are oftentimes exhorted to encourage (United Nations 1974). Of the alternative instruments that exist to encourage multinational r\&d and innovation, the strength of intellectual property protection in the host nation is arguably a potentially important one. ${ }^{2}$

The use of the instrument of intellectual property protection, however, has been extremely vexed. It was only after rather long drawn-out and bitter negotiations between 
the developing and developed countries that the agreement on Trade-Related Intellectual Property rights was inked in 1994. The actual implementation of the agreement, however, took several more years, with many developing countries amending their domestic intellectual property protection laws only by the very fag end of 2004, the end of their implementation period. And even so, in the field of agriculture, many countries opted for a sui generis form of protection that is considered weaker than patent protection.

One of the prime concerns, needless to add, has been whether stronger protection does in fact spur domestic innovation. The empirical evidence in this regard has not been very helpful either. While Sakakibara and Branstetter (2001), and Lerner (2002) find that stronger protection does not stimulate innovation, Kanwar and Evenson (2003), and Chen and Puttitanum (2005) find that it does. Even if the latter verdict is accepted, there is still not much clarity about which sectors of the economy would benefit the most from stronger protection. Mansfield (1986) and Levin et.al (1987) present somewhat impressionistic evidence based on surveys of r\&d executives in various American industries, to show that while patent protection is considered overwhelmingly important in the pharmaceuticals and chemicals industries, it rates much lower in the protection of other industries. Qian (2007) provides more rigorous evidence about the significance of protection for the pharmaceuticals industry. In her review of the available evidence, Hall (2007) adds software and biotechnology to this list. Empirical evidence also shows stronger protection to matter in the field of agriculture in general (Alfranca and Huffman 2003). ${ }^{3}$

Domestic innovation, however, is only part of the story. Stronger protection is also supposed to benefit technology transfer. None of the empirical studies cited in the 
previous paragraph consider this phenomenon. Of course, the transfer of technology is a complex process, and occurs through various means. Some of the more important channels appear to be trade, foreign direct investment, licensing and overseas r\&d by multinationals. Ferrantino (1993), Maskus and Penubarti (1995) and Smith (1999, 2001) provide evidence supporting the positive effect of stronger protection on trade. Similarly, Ferrantino (1993), Lee and Mansfield (1996), and Javorcik (2004) find that stronger protection encourages foreign direct investment. McCalman (2004) shows that, in the context of certain industries, this relationship is likely to be non-linear.

Both these forms of technology transfer are, however, indirect in nature. The more direct modes of transfer are licensing and overseas r\&d. ${ }^{4}$ Yang and Maskus (2001), and Branstetter, Fisman and Foley (2006) report that stronger protection does in fact stimulate technology transfer as measured by royalties and license fees. Note, however, that an increase in royalty and license fees could be entirely on account of an increase in the cost of technology transfer (i.e. the 'price' of the license so to speak), and does not necessarily imply an increase in the number of (new) licenses per se. Further, Branstetter, Fisman and Foley (2006) report rather weak results regarding the effect of stronger protection on overseas r\&d investment - the index of protection dummy they use is statistically insignificant in five of the six regressions reported (see their Table IV, p. 340). ${ }^{5}$ Additionally, their analysis is limited to mostly developing countries, which account for a very small percentage of the total r\&d investment undertaken by the majority-owned overseas affiliates of US firms. Thus, in 1999 (the end of their sample period), the countries in their sample accounted for just $16.2 \%$ of the total overseas $r \& d$ investment of the majority-owned foreign affiliates of US multinationals; and of this, 
about 8.4 percentage points was the share of Japan alone, implying that the remaining 15 countries accounted for less than $8 \%$ of the total overseas r\&d investment in question. Obviously, this would lead us to question the general applicability of their results.

Our study focuses on this latter-most mode of technology transfer - namely, the overseas r\&d investment by majority-owned foreign affiliates of US firms - and attempts to gauge whether, in what direction, and to what extent it is influenced by the strength of intellectual property protection that the host nations provide. In doing so, we consider all countries for which such (and other relevant) data are available, and do not limit the set of countries to just the developing or the developed. Nor does our analysis employ an index of protection measure that is episode-specific or country-specific. Using several alternative measures of the strength of intellectual property protection over the period 1977-99, our analysis shows that the strength of protection was probably an insignificant determinant of (at least this mode of) technology transfer. Subsequent analysis shows this result to be robust to the possibility of simultaneity bias. Section 2 fleshes out the basic estimation model of this paper, and extensions thereof. Section 3 provides some detailed information about the data employed. Section 4 discusses the estimation results. Section 5 deals with the possibility of endogeneity in the 'treatment variable'. And finally, section 6 briefly concludes.

\section{The Estimation Model}

\subsection{One mode of technology transfer}

The regressand in our estimation exercises is (the total) ${ }^{6}$ overseas research and development investment undertaken by the (majority-owned) affiliates of US firms in a 
given country, as a proportion of the gross product of these affiliates (RDPA). A majority-owned foreign affiliate is one in which the direct and indirect ownership interest of a US parent(s) exceeds 50\%; so that the latter may be presumed to exercise unambiguous control over the former. The r\&d investment undertaken by the affiliates in a given country may, then, be causally related to various characteristic features of both those affiliates as well as that (host) country. Of course, this variable is an underestimate of the technology transfer involved insofar as it does not account for the subsequent spillover effects. If host country protection levels are found to have a significant positive influence on our regressand, then its influence on the 'total' technology transfer may be even greater in view of the spillover effects. But if the host country protection levels are found to have an insignificant effect on our dependent variable, there may still be further scope for improving the estimation equation if the spillover effects could be included. There is, however, no obvious way of doing so.

\subsection{Factors which might explain such technology transfer}

\subsubsection{The 'treatment variable'}

The main regressor of interest or the 'treatment variable' in our model is the strength of intellectual property protection in the host countries, i.e. the countries receiving r\&d investment from US multinationals. Since this variable is of major interest, we use four different indices of this variable available in the literature; although for various reasons that we will make clear, the fourth is the most preferable of the four. The first index is taken from Mansfield (1993). His index of protection is based on the perception of a sample of major US firms, about how weak intellectual property protection was in 1991, 
in a given set of countries. Each firm was asked whether the protection in each of these countries was too weak to permit it to transfer its newest technology to a wholly-owned subsidiary there, to invest in joint ventures with local partners, and to license its newest technology to unrelated firms. The higher the percentage of firms that answered in the affirmative for a given country, the weaker the protection offered by that country. We, therefore, measure the strength of protection as 100 minus this percentage. This index (IP-M) varies between 0 and 100, with higher percentages indicating stronger protection.

The second index is taken from Rapp and Rozek (1990). Their index is based on a comparison of individual countries' patent laws with the guidelines proposed by the US Chamber of Commerce's Intellectual Property Task Force, in its Guidelines for Standards for the Protection and Enforcement of Patents. Their index (IP-RR) ranges from 0 to 5 , with higher numbers indicating greater conformity with the proposed guidelines, and thereby signifying stronger protection.

The third index that we employ is one that is reported by the World Economic Forum in its Global Competitiveness Report (World Economic Forum, various years). This index (IP-WEF) is based on surveys of the opinions and experiences of firms and individuals, regarding the strength of intellectual property protection in their specific countries. It is purportedly computed in this impressionistic manner precisely 'to capture what might not be reflected in official statistics'. It relates to the overall intellectual property climate in countries, as opposed to the Rapp and Rosek index and the GinartePark index (discussed next) both of which focus on patent rights only. While this may appear to be a strength of this index at first sight, it may well be its weakness insofar as 
countries provide differing strengths of protection to different forms of intellectual property.

The fourth index we use is taken from Ginarte and Park (1997), and their extensions of the same ${ }^{7}$. Their index is superior to those of Mansfield, Rapp and Rosek, as well as the World Economic Forum, in that it is not based on subjective or ad hoc perceptions; on the contrary, it employs objective criteria to manifest the strength of protection a nation provides. It considers several aspects of patent protection, which makes for greater variation in the index even for the developed countries. Specifically, it considers five aspects of patent laws - extent of coverage (i.e. the matter that can be patented), duration of protection (i.e. the number of years of protection), membership of international property rights agreements, potential restrictions on the exercise of the patent rights once granted (e.g. provisions such as compulsory licensing), and enforcement mechanisms. For each of these five aspects, a country receives a score ranging from 0 to 1 , a larger score indicating stronger protection in that aspect. The overall score is computed as the sum of the scores in the five individual categories. Therefore, the Ginarte-Park index (IP-GP) ranges from 0 to 5, with higher values indicating stronger patent protection. Not only is it computationally superior to the previous three indices defined above, it is also available for the largest set of countries and the maximum number of time periods. The coefficients of pair-wise correlation between the Mansfield, Rapp and Rosek, and World Economic Forum indices on the one hand, and the Ginarte-Park index on the other, are 0.60, 0.86 and 0.71, respectively.

Although the Ginarte-Park index considers 'membership of international property rights' agreements in attempting to manifest the strength of intellectual property 
protection in a country (which is a latent variable and needs to be manifested using instruments), some might point out that membership of the Trade Related Intellectual Property rights agreement (under the aegis of the World Trade Organization) has not been considered. To clarify further, this agreement was signed in 1994 (to be implemented commencing 1995), but the Ginarte-Park index for years subsequent to 1994 does not consider it. While this makes the index comparable over time, some would argue that it renders the index 'incomplete', for a case could be made that overseas r\&d investment by US firms might be influenced by whether a country is a member-signatory of the WTO. We cannot, however, allow for this factor by introducing a WTOmembership binary variable (equal to 1 if a country is a member-signatory and equal to 0 otherwise), because all the countries in our sample became members of the WTO in $1994,{ }^{8}$ so that the membership-dummy would be covariant with the year fixed effect, rendering estimation impossible. ${ }^{9}$ There is also the question of whether a WTOmembership dummy would reflect property rights concerns or primarily trade and investment concerns, given that the WTO agreement was more about the latter. In view of the fact that the TRIPs membership varies over time but not across our sample countries, it is best picked up by the year fixed effect.

\subsubsection{The control variables}

While the strength of intellectual property protection is the 'treatment variable' in our model, given that the treatment level has not been randomly assigned across countries, we need to control for the other factors that influence overseas r\&d by US multinationals. Research in this area shows that a lot of overseas $r \& d$ is undertaken to cater to the special 
design needs of the host markets (Mansfield, Teece and Romeo 1979). It is reasonable to argue that multinationals are likely to respond thus, only to the extent that the host market in question matters to them. Conversely, if the host country market is small, the multinationals are not likely to be sensitive to local requirements. The size of the host country market may, therefore, be used to represent this consideration for local/regional preferences. We use two variables to proxy this complex factor - first, the host country income per capita (GDPPC), and second the host country sales of the subsidiary $($ SALES $) .^{10}$

Internal funds are arguably very important for r\&d investment in general (Hall 1992) and, presumably, for overseas $r \& d$ investment as well. While parent multinationals may earmark funds for their overseas subsidiaries, an important component of subsidiary r\&d is likely to be the savings generated by the subsidiaries themselves. One reason why financial institutions are reluctant to lend for such purposes is the high risk factor of such investments; what return such investments are likely to fetch is highly uncertain. As a result, internal funds acquire a lot of importance. Using data on this variable obviates the need for separate data on variables such as host country corporate tax rates, because those would be implicit in the savings data. ${ }^{11}$ We capture this variable (SAVINGS) in terms of the net income of the majority-owned affiliates in various countries as a proportion of their gross product. Since the net income of affiliates is computed as gross revenue minus costs minus foreign taxes, it accounts for any r\&d tax incentives that foreign governments give to the affiliates. Usually, r\&d tax incentives allow the affiliates to pay taxes at some concessional tax rate (as compared to the rate at which they would have to pay if they did 
not conduct r\&d). Thus, r\&d tax incentives merely lower the affiliates’ tax liability, and leave them with a higher net income.

Multinationals conduct r\&d abroad to benefit from various local advantages that may obtain. Thus, the availability of abundant and well-qualified technical and scientific manpower in the host nation might be an attractor (Mansfield, Teece and Romeo 1979). Given the paucity of data on the stock of such manpower, however, we use the stock of human capital as a proxy. The latter is defined as the average number of years of higher education in the population aged 15 and over in the host country (HIGHEDU).

Openness of the host nation to trade and investment from abroad would be an important consideration in what r\&d investment it attracts. While none of the competing measures of openness available in the literature are entirely satisfactory in this regard, we use the black market exchange rate premium (see Gould and Gruben 1996; and the references cited therein). This is defined as the ratio of the black market exchange rate to the official exchange rate $(B M P)$.

The extent of economic freedom in the host country would be another factor of relevance to the magnitude of r\&d investment it attracts. One would reckon, that the more interventionist the government and the more controls it imposes on economic activity, the less attractive would be the market in question to foreign investors. Gwartney and Lawson (2004) consider ten different aspects of economic activity in devising their measures of economic freedom for different countries. We use their economic freedom rank index $(E F R)$ to represent this variable.

Given that our data relate to a disparate set of countries at different levels of economic development, we incorporate country fixed effects whenever possible. In some 
estimation exercises, however, this is not possible due to data limitations, and we clearly take note of this in our discussion of the results below. In addition, we also include time fixed effects wherever pertinent and possible (more on this below). Needless to add, exercises where we can allow for such effects are preferred over the others.

\section{Data Issues}

\subsection{Data and sources}

The data pertaining to the majority-owned foreign affiliates of US multinationals are those collected by the Bureau of Economic Analysis (BEA, various years) of the US Department of Commerce, for various 'benchmark years'. Benchmark surveys were conducted in 1966, 1977, 1982, 1989, 1994 and 1999, ${ }^{12}$ for the universe of US firms investing abroad. The published data, however, are country-level aggregates, i.e. for the sum total of the foreign affiliates (of US firms) in a given country, and these are the data we use. Given that data on many of the variables of interest to us are not available in the 1966 BEA survey, we drop that survey from our basic data set.

Data on all four indices of the strength of intellectual property protection that we mentioned above - IP-M, IP-RR, IP-WEF, and IP-GP - are not available for all the BEA survey years. Thus, the Mansfield index of protection IP-M is available for 1991 only, and we pair it with the 1989 BEA survey data. The Rapp-Rozek index of protection IP$R R$ is available for 1990 only, and again we pair it with the 1989 BEA survey data. The World Economic Forum index of protection IP-WEF is fortunately available for 1989,

1994, and 1999, and we pair these data with the 1989, 1994 and 1999 BEA survey data. ${ }^{13}$ Finally, the Ginarte-Park index of protection IP-GP is the only one that is available for all 
the years for which BEA data are available, roughly corresponding to the BEA survey years. Thus, we pair IP-GP data for 1975, 1980, 1990, 1995 and 2000 with the BEA survey data for 1977, 1982, 1989, 1994 and 1999, respectively.

Data on the host country variables were taken from several different sources. Per capita GDP figures (GDPPC) were taken from Heston, Summers and Aten (2006). The human capital variable 'average years of higher education in the population aged 15 and over' (HIGHEDU) was taken from Barro and Lee (2000). The series on the openness of the economy (BMP) was constructed from data in Pick's Currency Yearbook (various years), World Currency Yearbook (various years), and online from Global Financial Data. ${ }^{14}$ Finally, the economic freedom rank index $(E F R)$ was taken from Gwartney and Lawson (2004). We might add, that for a small number of observations, although data on the regressand and the 'treatment variable' were available, data on some of the other regressors discussed above were missing, and so these observations had to be dropped. In the regression exercises, all variables are defined in logarithms, except the binary variables.

\subsection{Outlining the sample}

The descriptive statistics presented in Table 1 pertain to the sample data used with the Ginarte-Park index of protection, because this data set was available for the largest set of countries and the longest time period. The data samples (of countries and time periods) used with the other measures of intellectual property protection are subsets of this sample. The descriptive statistics in question pertain to the untransformed variables. In addition, summary statistics regarding the other indices of protection are also provided as 
well. A cursory examination of the table reveals that the strength of intellectual property protection (as measured by $I P-G P$ as well as $I P-W E F$ ) rose substantially over the sample period, and so did the overseas r\&d investment performed by the affiliates of the US multinationals. This, of course, does not establish any concrete causal relationship between these two variables, and for that we proceed to more formal analysis.

We commence by considering the simple correlation coefficients between overseas r\&d investment performed by the affiliates, and each of the alternative indices of protection. The pair-wise correlation coefficients between RDPA on the one hand, and $I P-M, I P-R R, I P-W E F$ and $I P-G P$ on the other are, respectively, $0.42,0.50,0.42$, and 0.41. The corresponding pair-wise correlations between the logarithms of these variables are, in general, even larger at $0.32,0.63,0.55$, and 0.62 . We get a similar picture from the scatter-plots of $R D P A$ on each of the indices of protection (with the variables in logarithms), as is evident from Figure 1. Thus, the raw data for all the measures suggest a fairly strong, positive relationship between overseas r\&d investment by the affiliates of (US) multinationals and the strength of intellectual property protection. How strong this relationship is empirically, and whether it is causal in nature are issues that we attempt to address in the following section.

\section{Estimation Results}

\subsection{R\&D performed by affiliates and intellectual property protection (Mansfield index)}

We'd like to emphasize that we estimate this relationship merely out of curiosity, because

the lack of data on the Mansfield index of protection (available for just 15 countries $^{15}$ for the year 1991), constrains the size of the sample too heavily. Moreover, because the data 
pertain to only a single year, we can neither allow for country fixed effects nor for time fixed effects. A WTO-membership binary variable would not make sense in this regression, because it pertains to the pre-WTO period (given that the TRIPs agreement was signed in 1994). The results reported in Table 2 show that the index of protection variable $(I P-M)$ is statistically insignificant in explaining variations in technology transfer. In the regression results of column (1), it appears that the index of protection has a large, positive effect on the regressand, even though insignificant. Even though the number of observations is too few to allow us to introduce cross-section dummies, as we noted above, we try and make up for this deficiency by introducing dummies $L A D$ (which equals 1 for Latin American countries, and is 0 otherwise) and $D C D$ (which equals 1 for Developed Countries and is 0 otherwise). The omitted category is the Afro-Asian dummy, which equals 1 for Asian or African countries and is 0 otherwise. ${ }^{16}$ With the addition of these 'region' dummies, ${ }^{17}$ as the column (2) regression shows, the effect of $I P-M$ on the dependent variable is, in fact, very small, possibly close to zero. The regression reported in column (3) includes various control variables in addition to the region dummies. While most of the regressors have the expected signs, none are significant in explaining the variation in the dependent variable. The base specification reported in column (4) improves upon that in column (3) by allowing for the presence of heteroscedasticity and autocorrelation. Although the results are qualitatively no different from those in column (3), the hypothesis that the regressand is randomly determined can now be rejected, the $p$-value of the associated test being 0.077 . The alternative specification reported in column (5) does not improve upon that in column (4) in any way. A common feature of all the regression results is the large standard errors associated 
with the index of protection variable, as one would expect from the miserably small number of observations available. In fact, it would have been surprising had the results been any different.

\subsection{R\&D performed by affiliates and intellectual property protection (Rapp-Rozek index)}

As for the previous index of protection, the Rapp and Rosek index is also available for just one year (1990), but fortunately the sample of countries is much larger at 37. But because the data pertain to a single year only, we can neither allow for country fixed effects nor for time fixed effects. As above, however, we attempt to make up for this shortcoming by introducing the 'region' dummies $L A D$ and $D C D$. A WTO-membership binary variable would not make sense in this regression either, because it pertains to the pre-WTO period as in the previous case. We immediately notice the benefit of the larger (and hence more varied) sample, from the results reported in Table 3. The hypothesis that all regressors are identically zero is strongly rejected at the $1 \%$ level, the $p$-value of the associated test being 0.000 for virtually all the reported regressions. The index of protection variable (IP-RR) is positive and highly significant in explaining variations in technology transfer. In the regression results of column (1), it appears that the index of protection has a large, positive and significant effect on the regressand. With the addition of the region dummies in the column (2) regression, the effect of $I P-R R$ on the dependent variable is still large and significant. The regression reported in column (3) includes various control variables in addition to the region dummies. While most of the regressors have the expected signs, none are significant in explaining the variation in the dependent variable. The base specification reported in column (4) corrects for the possible presence 
of heteroscedasticity and autocorrelation in the data. ${ }^{18}$ The results are qualitatively and quantitatively virtually unaltered. The alternative specification reported in column (5) improves slightly upon that in column (4) insofar as the SALES variable is now strongly significant in explaining technology transfer. Note, however, that the $95 \%$ confidence interval of the index of protection variable $(0.34,2.73)$ is still very large, and the coefficient estimate of this variable reduces substantially in magnitude, indicating the presence of omitted variable bias as well as very low precision. Keeping in mind that country and year fixed effects were not feasible given the data constraints, we cannot place much confidence in these results.

\subsection{R\&D performed by affiliates and intellectual property protection (World Economic} Forum index)

The intellectual property protection variable reported by the Global Competitiveness Report of the World Economic Forum, is available for various countries for three of the years for which BEA data are available on the overseas r\&d investment of US firms namely 1989, 1994 and 1999. Consequently, we have a respectable-sized panel for use with this measure of intellectual property IP-WEF. Further, this time series variation permits us to allow for country fixed effects as well as time fixed effects, neither of which was possible with the previous two measures. Note that the time fixed effects would reflect all factors that change with time but remain the same across countries, membership of the WTO being one of them. From Table 4 we find that the hypothesis that all regressors are identically zero is strongly rejected at the $1 \%$ level, the $p$-value of the associated test being 0.000 for all the regressions. The regression results in column 
(1) reveal that the index of protection variable IP-WEF is positive and strongly statistically significant in explaining variations in technology transfer. When we add country fixed effects (and use heteroscedasticity and autocorrelation-robust standard errors), as in the column (2) regression, although variable IP-WEF continues to be significant, its coefficient estimate halves in numerical magnitude. When we add the year fixed effects, as in the column (3) regression, the index of protection variable becomes insignificant and its coefficient estimate becomes virtually zero. The base specification, including the control variables, is presented in column (4), and it reveals that only the internal funds variable SAVINGS is (strongly) significant. Although the index of protection variable continues to have a virtually zero coefficient, the associated $95 \%$ confidence interval $(-0.95,1.16)$ is still quite large, so that large negative or positive effects cannot be ruled out. The important point, however, is that there isn't sufficient identifying variation in this variable. The alternative specification results reported in column (5) do not alter the base specification results in any serious manner, except that the added variable SALES is also strongly significant.

4.4 R\&D performed by affiliates and intellectual property protection (Ginarte-Park index)

The Ginarte-Park index of protection is available for all five years for which BEA data are available on overseas r\&d by US firms - namely 1977, 1982, 1989, 1994 and 1999. Consequently, we have the largest sample for use with this measure of intellectual property. The panel data allow us to include both country fixed effects and year fixed effects in our regressions. Table 5 reveals, that the hypothesis that overseas r\&d by the 
majority-owned affiliates of US firms is randomly determined is strongly rejected, the $p$ value of the corresponding test being 0 in all the regressions. The column (1) regression suggests that the intellectual property protection variable $I P-G P$ has a strong and large positive effect on technology transfer. The addition of country fixed effects (and use of heteroscedasticity and autocorrelation-robust standard errors), as in the column (2) regression, however, reduces the positive effect of this regressor to less than a third of its previous value, although the regressor continues to be significant. The addition of the time fixed effects, as in the column (3) results, further reduces the effect of the index of protection variable to virtually zero, and it is no longer statistically significant either. The associated $95 \%$ confidence interval $(-0.25,0.17)$ not only contains the zero value firmly in the middle, but is also quite narrow, implying a high degree of precision. The time dummies taken together are significantly different from zero, indicating that forces such as the globalization of world trade and investment pre-dating the WTO might be responsible for the increase in overseas $r \& d$ by multinationals, rather than any strengthening of the intellectual property regime. These results do not change in any substantial manner upon the addition of the control variables as in the base specification reported in column (4). Nor do they change with the addition of other controls as in the alternative specification reported in column (5).

The choice to express the dependent variable as overseas $r \& d$ as a proportion of gross product, was made to allow for the differing magnitudes of affiliate operations in different countries. Of course, if both $r \& d$ and other complementary activities increase pari passu, the share of activity that is r\&d may not go up, even if the level of r\&d does. To take care of this, we repeat the above estimations with the dependent variable defined 
simply as the (total) overseas research and development investment undertaken by the (majority-owned) affiliates of US firms in a given country $(R D)$. To control for affiliate size, we now include gross product $(G P)$ as an additional regressor. The results are reported in Table 6. Suffice it to note, that they are much the same as those discussed above using RDPA as the dependent variable and, therefore, need not be discussed in detail. ${ }^{19}$ In the subsequent analysis, we restrict ourselves to the use of $R D P A$ as the dependent variable (rather than $R D$ ), because this does not appear to influence the results and avoids repetition.

4.5 R\&D performed by affiliates and intellectual property protection - standardized coefficients

Although we have noted clearly the relative strengths of the Ginarte-Park measure of protection and, therefore, our preference for the estimation results using this measure, presentation of the results for the four alternative measures makes it natural for the reader to want to be able to compare the coefficient magnitudes across specifications. The elasticities, however, are not necessarily comparable - a $10 \%$ change in protection measures of very different scales and distributions across countries, may represent very different implied movements in the distribution of patent protection. To enable such comparison for those who might be interested, we compute standardized coefficients of the 'treatment variable', using the base specification results for each of the four measures of protection (i.e. column (4) of Tables 2, 3, 4 and 5). From the standardized coefficients reported in Table 7, we again find that IP-GP has a very small effect on the overseas r\&d by affiliates. Thus, a one standard deviation increase in the index of protection (which 
would, for instance, take a country from the $25^{\text {th }}$ percentile to the $75^{\text {th }}$ percentile), would raise overseas r\&d by a mere 0.014 standard deviation units. Even the $95 \%$ confidence interval for this standardized coefficient $(-0.07,0.10)$ indicates an economically insignificant effect.

4.6 R\&D performed by affiliates and intellectual property protection - an alternative interpretation

It may be argued that not any increase in the strength of intellectual property protection matters. Thus, an increase in the strength of protection may not matter at all (for overseas r\&d, in the present context) if the higher level of protection is still 'too low', i.e. below some threshold. Similarly, an increase in the strength of protection may have only a marginal incremental effect if the strength of protection was already above some threshold to begin with. In other words, what may matter is an increase in the strength of protection from below some threshold to above the threshold. To test this hypothesis we re-define the Ginarte-Park index of protection (IP-GP) as a binary variable, which equals 1 if it equals or exceeds the median level of protection in a given year and equals 0 otherwise. ${ }^{20}$ We label this dummy variable IP-GPD. We prefer to work with the GinartePark index because of the various advantages it has over the other indices, as pointed out above.

Column (1) of Table 8 shows that the index of protection dummy has a large, positive and significant effect on the dependent variable. When we add the country fixed effects, however, the coefficient estimate of this regressor becomes very small and insignificant. The associated $95 \%$ confidence interval $(-0.61,0.84)$ is somewhat wide, 
though it does contain the zero value. The addition of the year fixed effects in the column (3) regression, and the addition of the controls in the base specification in the column (4) regression, both lead to a reduction of the effect of the index of protection dummy to virtually zero. The $95 \%$ confidence interval $(-0.47,0.57)$ of this variable is now tighter, and includes a zero value of the true effect (as it did before). The picture is no different in the alternative specification of column (5). In other words, this alternative interpretation of the influence of a strengthening of protection is perfectly in line with our earlier results, which suggest the lack of any relationship between technology transfer as measured by overseas r\&d performed by the affiliates of US multinationals and the strength of protection offered by the host country.

\section{Endogeneity of the 'treatment variable'}

The literature on intellectual property cautions us that the index of protection may not be exogenous (Lerner 2002; Ginarte and Park 1997). Although the argument traditionally made is in a somewhat different context (that the relationship between domestic innovation and strength of protection may be bi-causal), a similar argument may be made in the present context as well. To wit, countries that attract relatively higher levels of overseas r\&d investment provide relatively stronger protection to intellectual property. Alternatively, there may be 'third factors' (such as political pressure) that push both overseas r\&d as well as the strength of protection in an upward direction. It is very difficult to correct for this possibility given the lack of convincing instruments for the strength of intellectual property protection. In fact, one often feels that there's nothing

called a perfect instrument. ${ }^{21}$ Short of instrumental variable estimation, therefore, we 
adopt the following strategy to gauge the possibility of reverse causation in the present context. Once again, we undertake this analysis only for the Ginarte-Park index of protection.

First we estimate a series of regressions wherein we regress the dependent variable RDPA on contemporaneous and following period values of the index of protection IP-GP individually. From the regression results presented in Table 9, we note that the coefficient estimates, t-statistics, and the summary statistics are relatively better for the regressions which use contemporaneous values of the index of protection as compared to the corresponding regressions which include the following period value of this regressor. More precisely, a comparison of columns (1) and (2) shows the former (i.e. the regression with contemporaneous $I P-G P$ ) to be superior. When country fixed effects (and heteroscedasticity and autocorrelation-robust standard errors) are allowed for, as in columns (3) and (4), again the former results (with contemporaneous IP-GP) are found to be superior. The same is found to be true when year fixed effects are added, as in the regressions reported in columns (5) and (6). Finally, when the controls are also included, as in the regressions of columns (7) and (8), while the coefficient of IP-GP becomes very small and insignificant in both regressions, it is relatively larger (and has a t-statistic larger than 1) in the former. These results suggest, that the causation probably runs from the index of protection to overseas r\&d investment, rather than vice versa.

Next we conduct a Sims (1972) type test wherein we regress $R D P A$ on both contemporaneous and following period IP-GP together. From the results in Table 10, we find that again the performance of contemporaneous IP-GP is relatively better. This holds true whether we estimate a simple OLS regression (as in column (1)), whether we allow 
for country fixed effects and use heteroscedasticity and autocorrelation-robust standard errors (as in column (2)), whether we then include year fixed effects as well (as in column (3), whether we estimate the base specification (as in column (4), or whether we estimate the alternative specification (as in column (5)). Putting together the results of both these causality investigations, we are led to believe that the strength of intellectual property protection probably drives the magnitude of overseas $r \& d$, rather than the other way round. Further, if the reverse causality is one where higher overseas r\&d induces higher strengths of protection from countries, this would have imparted an upward bias to the relationship between our dependent variable RDPA and the 'treatment variable' $I P$ $G P$, rendering it more positive than it would be in the absence of this bias stemming from the reverse causality. That would have been an issue had we found a large, positive and significant relationship between the variables of interest. As it turns out, however, our results reveal a near zero influence of the strength of protection on overseas r\&d; implying that whatever upward bias there may be on account of the reverse causality is probably unimportant.

\section{Rounding Up}

In the literature on intellectual property, one comes across claims about the influence that the strength of intellectual property protection may have on several key economic phenomena. One such is the effect that intellectual property protection has on technology transfer via overseas r\&d investment by multinationals. This paper attempts to gauge the strength of this empirical relationship. Using cross-country panel data spanning the period 1977-1999, we find little support for the claim that strengthening intellectual 
property rights will have any sizable effect on the magnitude of overseas r\&d investment by (US) multinationals. Any semblance of a positive relationship between these two variables vanishes the moment we introduce country fixed effects and time fixed effects into the regressions. The addition of control variables does not alter the picture in any appreciable manner. One implication of our results is, that a tightening of intellectual property rights by the developing countries pursuant to the TRIPs agreement, may not have any significant influence on technology transfer via overseas r\&d into these countries, ceteris paribus. Of course, this by itself does not call into question the overall utility of strengthening intellectual property rights; that would also depend upon the extent to which such policies affect the other key economic phenomena they are claimed to. 


\section{References}

Alfranca, Oscar and Wallace E. Huffman 2003, ‘Aggregate Private R\&D Investments in Agriculture: The Role of Incentives, Public Policies, and Institutions’, Economic Development and Cultural Change, 52(1), 1-21.

Barro, Robert J. and Jong-Wha Lee 2000, International Data on Educational Attainment: Updates and Implications, CID Working Paper No. 42, Harvard University.

Branstetter, Lee G., Raymond Fisman and C. Fritz Foley 2006, ‘Do Stronger Intellectual Property Rights Increase International Technology Transfer? Empirical Evidence From U.S. Firm-Level Panel Data’, Quarterly Journal of Economics, 121(1), 321349.

Bureau of Economic Analysis, U.S. Direct Investment Abroad, U.S. Department of Commerce, Washington, D.C., various years.

Chen, Youngmin and Thitima Puttitanum 2005 'Intellectual Property Rights and Innovation in Developing Countries', Journal of Development Economics, 78(2), 474-493.

Davis, Lee 2004, ‘Intellectual Property Rights, Strategy and Policy’, Economic Innovation and New Technology, 13(5), 399-415.

Ferrantino, Michael J. 1993, ‘The Effects of Intellectual Property Rights on International Trade and Investment', Weltwirtschaftliches Archic, 129(2), 300-331.

Ginarte, Juan C. and Walter G. Park 1997, 'Determinants of Patent Rights: A CrossNational Study’, Research Policy, 26(3), 283-301.

Global Financial Data, available at <www.globalfinancialdata.com>

Gould, David M. and William C. Gruben 1996, 'The role of intellectual property rights in 
economic growth', Journal of Development Economics, 48(2), 323-350.

Granstrand, Ove, Lars Hakanson and Soren Sjolander 1993, 'Internationalization of R\&D - a survey of some recent research', Research Policy, 22(5-6), 413-430.

Gwartney, James and Robert Lawson 2004, Economic Freedom of the World: 2004 Annual Report, The Fraser Institute, Vancouver, BC; data from www.freetheworld.com.

Hall, Bronwyn 1992, Investment and $r \& d$ at the firm level: does the source of financing matter?, Working Paper no. 4096, National Bureau of Economic Research, Cambridge, MA.

Hall, Bronwyn 2007, 'Patents and Patent Policy', Oxford Review of Economic Policy, Forthcoming.

Harrison, Ann 1994, 'The Role of Multinationals in Economic Development: The Benefits of FDI', Columbia Journal of World Business, 29(4), 6-11.

Heston, Alan, Robert Summers and Bettina Aten 2006, Penn World Table Version 6.2, Center for International Comparisons of Production, Income and Prices, University of Pennsylvania.

Javorcik, Beata Smarzynska 2004, ‘Composition of Foreign Direct Investment and Intellectual Property Rights: Evidence from Transition Economics’, European Economics Review, 48(1), 39-62.

Kanwar, Sunil and Robert E. Evenson 2003, 'Does Intellectual Property Protection Spur Technological Change?’, Oxford Economic Papers, 55(2), 235-264.

Kumar, Nagesh 1996, 'Intellectual Property Protection, Market Orientation and Location of Overseas R\&D Activities by Multinational Enterprises’, World Development, 
24(4), 673-688.

Lee, Jeong-Yeon and Edwin Mansfield 1996, 'Intellectual Property Protection and U.S. Foreign Direct Investment', Review of Economics and Statistics, 78(2), 181-186.

Lerner, Josh 2002, '150 Years of Patent Protection’, American Economic Review, 92(2), 221-225.

Levin, Richard C., Alvin K. Klevorick, Richard R. Nelson, Sidney G. Winter 1987, 'Appropriating the Returns from Industrial Research and Development', Brookings Papers on Economic Activity, 1987(3), 783-831.

Mansfield, Edwin 1986, 'Patents and Innovation: An Empirical Study’, Management Science, 32(2), 173-181.

Mansfield, Edwin 1993, 'Unauthorized Use of Intellectual Property: Effects on Investment, Technology Transfer, and Innovation’ in M. Wallerstein, M. Mogee, and R. Schoen (eds.) Global Dimensions of Intellectual Property Rights in Science and Technology, National Academy Press, Washington, D.C.

Mansfield, Edwin, David Teece and Anthony Romeo 1979, 'Overseas Research and Development by US-Based Firms’, Economica, 46(2), 187-196.

Maskus, Keith E. and Mohan Penubarti 1995, 'How Trade-Related are Intellectual Property Rights’, Journal of International Economics, 39(2), 227-248.

McCalman, Phillip 2001, 'Reaping What You Sow: An Empirical Analysis of International Patent Harmonization’, Journal of International Economics, 55(1), $161-186$

McCalman, Phillip 2004, 'Foreign Direct Investment and Intellectual Property Rights: Evidence from Hollywood's Global Distribution of Movies and Videos', Journal 
of International Economics, 62(1), 107-123.

McCalman, Phillip 2005, 'Who Enjoys TRIPs Abroad: An Empirical Analysis of Intellectual Property Rights in the Uruguay Round', Canadian Journal of Economics, 38(12), 574-603.

Pick’s Currency Yearbook, various years, Pick Publishing Corporation, New York. Qian, Yi 2007, 'Do Additional National Patent Laws Stimulate Domestic Innovation in a Global Patenting Environment: A Cross-Country Analysis of Pharmaceutical Patent Protection 1978-1999', Review of Economics and Statistics, forthcoming.

Rapp, Richard T. and Richard P. Rozek 1990, 'Benefits and Costs of Intellectual Property Protection in Developing Countries', Journal of World Trade, 24(1), 75-102.

Sakakibara, Mariko and Lee G. Branstetter 2001, 'Do Stronger Patents Induce More Innovation? Evidence from the 1988 Japanese Patent Law Reforms', RAND Journal of Economics, 32(1), 77-100.

Scotchmer, Suzanne 2004, Innovation and Incentives, MIT Press, Cambridge.

Sims, Christopher A. 1972, ‘Money, Income and Causality’, American Economic Review, 62(4), 540-552.

Smith, Pamela 1999, ‘Are Weak Patent Rights a Barrier to U.S. Exports?’, Journal of International Economics, 48(1), 151-177.

Smith, Pamela 2001, 'How do Foreign Patent Rights Affect U.S. Exports, Affiliate Sales and Licenses?', Journal of International Economics, 55(1), 411-439.

Stock, James H. and Mark W. Watson 2007, Introduction to Econometrics, AddisonWesley, Boston.

United Nations 1974, The Impact of Multinational Corporations on Development and on 
International Relations, New York.

World Currency Yearbook, various years, International Currency Analysis Inc., New York.

World Economic Forum, various years, Global Competitiveness Report, Oxford University Press, Oxford.

Yang, Guifang and Keith E. Maskus 2001, 'Intellectual Property Rights and Licensing: An Econometric Investigation', Weltwirtschaftliches Archiv, 137(1), 58-79. 
Table 1: Descriptive Statistics for the data set

\begin{tabular}{|c|c|c|c|c|c|c|}
\hline \multirow{2}{*}{ Variable } & \multicolumn{5}{|c|}{ Benchmark Years } & \multirow{2}{*}{$\begin{array}{l}\text { Full period } \\
1977-1999\end{array}$} \\
\hline & 1977 & 1982 & 1989 & 1994 & 1999 & \\
\hline \multicolumn{7}{|c|}{ Overseas Affiliates’ Characteristics } \\
\hline $\mathrm{RD}$ & $\begin{array}{l}61.45 \\
(115.82)\end{array}$ & $\begin{array}{l}108.34 \\
(237.36)\end{array}$ & $\begin{array}{l}210.76 \\
(440.23)\end{array}$ & $\begin{array}{l}303.29 \\
(616.32)\end{array}$ & $\begin{array}{l}489.20 \\
(917.76)\end{array}$ & $\begin{array}{l}237.44 \\
(562.63)\end{array}$ \\
\hline GP & $\begin{array}{l}3806.21 \\
(6121.91)\end{array}$ & $\begin{array}{l}5613.54 \\
(9070.11)\end{array}$ & $\begin{array}{l}8146.76 \\
(13158.50)\end{array}$ & $\begin{array}{l}9910.92 \\
(15264.58)\end{array}$ & $\begin{array}{l}14520.09 \\
(21985.74)\end{array}$ & $\begin{array}{l}8473.75 \\
(14585.19)\end{array}$ \\
\hline SALES & $\begin{array}{l}11555.67 \\
(18423.41)\end{array}$ & $\begin{array}{l}17667.69 \\
(26816.68)\end{array}$ & $\begin{array}{l}25893.19 \\
(41962.27)\end{array}$ & $\begin{array}{l}34774.76 \\
(52413.80)\end{array}$ & $\begin{array}{l}56400.00 \\
(79267.27)\end{array}$ & $\begin{array}{l}29512.33 \\
(50777.68)\end{array}$ \\
\hline SAVINGS & $\begin{array}{l}466.70 \\
(722.64)\end{array}$ & $\begin{array}{l}522.20 \\
(833.16)\end{array}$ & $\begin{array}{l}1676.54 \\
(2453.64)\end{array}$ & $\begin{array}{l}1814.92 \\
(2289.72)\end{array}$ & $\begin{array}{l}3701.94 \\
(5559.64)\end{array}$ & $\begin{array}{l}1653.06 \\
(3136.36)\end{array}$ \\
\hline \multicolumn{7}{|c|}{ Host Country Characteristics } \\
\hline GDPPC & $\begin{array}{l}4779.37 \\
(2588.84)\end{array}$ & $\begin{array}{l}7591.38 \\
(3963.68)\end{array}$ & $\begin{array}{l}11096.05 \\
(5914.33)\end{array}$ & $\begin{array}{l}13773.13 \\
(7283.46)\end{array}$ & $\begin{array}{l}16871.08 \\
(8828.01)\end{array}$ & $\begin{array}{l}10942.91 \\
(7441.87)\end{array}$ \\
\hline BMP & $\begin{array}{l}1.31 \\
(0.73)\end{array}$ & $\begin{array}{l}1.32 \\
(0.63)\end{array}$ & $\begin{array}{l}1.20 \\
(0.55)\end{array}$ & $\begin{array}{l}1.10 \\
(0.38)\end{array}$ & $\begin{array}{l}1.00 \\
(0.01)\end{array}$ & $\begin{array}{l}1.18 \\
(0.53)\end{array}$ \\
\hline EFR & $\begin{array}{l}31.33 \\
(19.31)\end{array}$ & $\begin{array}{l}37.2 \\
(27.1)\end{array}$ & $\begin{array}{l}33.08 \\
(28.28)\end{array}$ & $\begin{array}{l}33.42 \\
(28.85)\end{array}$ & $\begin{array}{l}34.17 \\
(28.41)\end{array}$ & $\begin{array}{l}33.85 \\
(26.53)\end{array}$ \\
\hline HIGHEDU & $\begin{array}{l}0.22 \\
(0.18)\end{array}$ & $\begin{array}{l}0.27 \\
(0.21)\end{array}$ & $\begin{array}{l}0.35 \\
(0.23)\end{array}$ & $\begin{array}{l}0.44 \\
(0.24)\end{array}$ & $\begin{array}{l}0.51 \\
(0.26)\end{array}$ & $\begin{array}{l}0.36 \\
(0.25)\end{array}$ \\
\hline IP-GP & $\begin{array}{l}2.59 \\
(0.81)\end{array}$ & $\begin{array}{l}2.80 \\
(0.96)\end{array}$ & $\begin{array}{l}2.83 \\
(1.02)\end{array}$ & $\begin{array}{l}3.23 \\
(0.82)\end{array}$ & $\begin{array}{l}3.63 \\
(0.73)\end{array}$ & $\begin{array}{l}3.02 \\
(0.94)\end{array}$ \\
\hline IP-WEF & & & $\begin{array}{l}5.48 \\
(1.34)\end{array}$ & $\begin{array}{l}6.06 \\
(1.60)\end{array}$ & $\begin{array}{l}6.93 \\
(1.38)\end{array}$ & $\begin{array}{l}6.23 \\
(1.55)\end{array}$ \\
\hline IP-RR & & & $\begin{array}{l}3.41 \\
(1.48)\end{array}$ & & & $\begin{array}{l}3.41 \\
(1.48)\end{array}$ \\
\hline IP-M & & & $\begin{array}{l}76.71 \\
(10.19)\end{array}$ & & & $\begin{array}{l}76.71 \\
(10.19)\end{array}$ \\
\hline
\end{tabular}

Note: The variables are untransformed.

Standard deviations are given in parentheses below the corresponding means.

The units of these variables are: RD (\$ million), GP (\$ million), SALES (\$ million), GDPPC (2000 PPP \$), BMP (ratio), EFR (rank number), HIGHEDU (number of years), IP-GP (index), IP-WEF (index), IP-RR (index), IP-M (index). 
Table 2: The Effect of Intellectual Property Protection (Mansfield Index) Dependent variable - RDPA

$\begin{array}{llllll}\text { Regressor } & (1) & (2) & (3) & (4) & (5) \\ \text { IP-M } & 2.892 & -0.292 & -3.452 & -3.452 & -0.956 \\ \text { GDPPC } & (2.357) & (3.315) & (5.905) & (3.735) & (3.363) \\ \text { SALES } & & & 0.848 & 0.848 & 1.350^{* *} \\ & & & (1.121) & (0.709) & (0.642) \\ \text { SAVINGS } & & & & -0.719 \\ & & & & & (0.305) \\ \text { HIGHEDU } & & & (0.115 & 0.115 & 0.272 \\ & & & 0.564 & (0.197) & (0.181) \\ \text { BMP } & & & (0.615) & (0.364 & 0.412 \\ & & & 0.386 & 0.386 & (0.339) \\ \text { EFR } & & & (2.043) & (1.292) & 2.648 \\ & & & (0.127 & 0.127 & -0.004 \\ \text { Constant } & & & (0.633) & (0.400) & (0.346) \\ & (10.214) & (14.170) & (26.882) & (17.001) & (15.002) \\ \text { Region dummies } & \text { No } & \text { Yes } & \text { Yes } & \text { Yes } & \text { Yes } \\ \text { HAC } & \text { No } & \text { No } & \text { No } & \text { Yes } & \text { Yes } \\ \text { N } & 15 & 15 & 15 & 15 & 15 \\ \text { P (region dummies } 0) & & 0.4187 & 0.6315 & 0.2888 & 0.0182 \\ \text { P (all slopes 0) } & 0.2415 & 0.3805 & 0.6825 & 0.0774 & 0.0030 \\ \bar{R}^{2} & 0.0349 & 0.0264 & -0.1998 & 0.1002 & 0.2490\end{array}$

Note: All variables are in natural logarithms except the dummies. HAC refers to heteroscedasticity and autocorrelation consistent standard errors. *** denotes significance at the $1 \%$ level; ** denotes significance at the $5 \%$ level. 
Table 3: The Effect of Intellectual Property Protection (Rapp-Rozek Index) Dependent variable - RDPA

\begin{tabular}{|c|c|c|c|c|c|}
\hline Regressor & (1) & $(2)$ & (3) & (4) & (5) \\
\hline \multirow[t]{2}{*}{ IP-RR } & $1.781^{* * *}$ & $1.933^{* * *}$ & $1.684^{* *}$ & $1.684^{* *}$ & $1.536^{* *}$ \\
\hline & $(0.373)$ & $(0.503)$ & $(0.760)$ & $(0.661)$ & $(0.611)$ \\
\hline \multirow[t]{2}{*}{ GDPPC } & & & 0.411 & 0.411 & 0.354 \\
\hline & & & $(0.607)$ & $(0.528)$ & $(0.487)$ \\
\hline SALES & & & & & $\begin{array}{l}0.376^{* * * *} \\
(0.146)\end{array}$ \\
\hline \multirow[t]{2}{*}{ SAVINGS } & & & -0.002 & -0.002 & 0.085 \\
\hline & & & $(0.182)$ & $(0.159)$ & $(0.150)$ \\
\hline \multirow[t]{2}{*}{ HIGHEDU } & & & 0.206 & 0.206 & 0.333 \\
\hline & & & $(0.322)$ & $(0.280)$ & $(0.263)$ \\
\hline \multirow[t]{2}{*}{ BMP } & & & 1.242 & 1.242 & 0.415 \\
\hline & & & $(1.126)$ & $(0.980)$ & $(0.958)$ \\
\hline \multirow[t]{2}{*}{ EFR } & & & 0.030 & 0.030 & 0.353 \\
\hline & & & $(0.244)$ & $(0.212)$ & $(0.232)$ \\
\hline \multirow[t]{2}{*}{ Constant } & $-7.319^{* * *}$ & $-7.557^{* * *}$ & $-10.561^{* *}$ & $-10.561^{* *}$ & $-13.707^{* * *}$ \\
\hline & $(0.549)$ & $(0.669)$ & $(5.189)$ & $(4.514)$ & $(4.333)$ \\
\hline Region dummies & No & Yes & Yes & Yes & Yes \\
\hline HAC & No & No & No & Yes & Yes \\
\hline $\mathrm{N}$ & 37 & 37 & 37 & 37 & 37 \\
\hline $\mathrm{P}$ (region dummies 0 ) & & 0.8044 & 0.5967 & 0.4991 & 0.2026 \\
\hline P (all slopes 0 ) & 0.0000 & 0.0006 & 0.0124 & 0.0001 & 0.0000 \\
\hline $\bar{R}^{2}$ & 0.3771 & 0.3480 & 0.3178 & 0.3633 & 0.4414 \\
\hline
\end{tabular}

Note: All variables are in natural logarithms except the dummies. HAC refers to heteroscedasticity and autocorrelation consistent standard errors. *** denotes significance at the $1 \%$ level; ** denotes significance at the $5 \%$ level. 
Table 4: The Effect of Intellectual Property Protection (World Economic Forum Index) Dependent variable - RDPA

\begin{tabular}{|c|c|c|c|c|c|}
\hline Regressor & (1) & (2) & (3) & (4) & (5) \\
\hline \multirow[t]{2}{*}{ IP-WEF } & $2.497^{* * *}$ & $1.237^{* * *}$ & 0.024 & 0.104 & 0.357 \\
\hline & $(0.372)$ & $(0.283)$ & $(0.559)$ & $(0.523)$ & $(0.526)$ \\
\hline \multirow{2}{*}{ GDPPC } & & & & -1.000 & -1.472 \\
\hline & & & & (1.178) & $(1.260)$ \\
\hline \multirow[t]{2}{*}{ SALES } & & & & & 0.817 \\
\hline & & & & & $(0.368)$ \\
\hline \multirow[t]{2}{*}{ SAVINGS } & & & & $0.129^{* *}$ & 0.186 \\
\hline & & & & $(0.057)$ & $(0.089)$ \\
\hline \multirow[t]{2}{*}{ HIGHEDU } & & & & -0.013 & 0.303 \\
\hline & & & & $(0.928)$ & $(0.746)$ \\
\hline \multirow[t]{2}{*}{ BMP } & & & & 0.298 & 0.492 \\
\hline & & & & $(0.460)$ & $(0.496)$ \\
\hline \multirow[t]{2}{*}{ EFR } & & & & 0.011 & 0.089 \\
\hline & & & & $(0.279)$ & $(0.284)$ \\
\hline \multirow[t]{2}{*}{ Constant } & $-8.993^{* * *}$ & $-6.734^{* * *}$ & -4.992 & -4.087 & 0.769 \\
\hline & $(0.675)$ & $(0.507)$ & $(0.892)$ & $(11.327)$ & $(11.242)$ \\
\hline Country fixed effects & No & Yes & Yes & Yes & Yes \\
\hline Year fixed effects & No & No & Yes & Yes & Yes \\
\hline HAC & No & Yes & Yes & Yes & Yes \\
\hline $\mathrm{N}$ & 105 & 105 & 105 & 105 & 105 \\
\hline P (year fixed effects 0 ) & & & 0.0000 & 0.0481 & 0.0165 \\
\hline P (all slopes 0 ) & 0.0000 & 0.0001 & 0.0001 & 0.0030 & 0.0016 \\
\hline $\bar{R}^{2}$ & 0.2978 & 0.1407 & 0.2837 & 0.2652 & 0.2570 \\
\hline
\end{tabular}

Note: All variables are in natural logarithms except the dummies.

HAC refers to heteroscedasticity and autocorrelation consistent standard errors. *** denotes significance at the $1 \%$ level; ** denotes significance at the $5 \%$ level. 
Table 5: The Effect of Intellectual Property Protection (Ginarte-Park Index) Dependent variable - RDPA

\begin{tabular}{|c|c|c|c|c|c|}
\hline Regressor & (1) & (2) & (3) & (4) & (5) \\
\hline \multirow[t]{2}{*}{ IP-GP } & $1.712^{* * *}$ & 0.514 & -0.039 & 0.040 & 0.045 \\
\hline & $(0.164)$ & $(0.208)$ & $(0.105)$ & $(0.121)$ & $(0.146)$ \\
\hline \multirow[t]{2}{*}{ GDPPC } & & & & -0.157 & -0.178 \\
\hline & & & & $(0.461)$ & $(0.586)$ \\
\hline \multirow[t]{2}{*}{ SALES } & & & & & 0.013 \\
\hline & & & & & $(0.173)$ \\
\hline \multirow[t]{2}{*}{ SAVINGS } & & & & 0.078 & 0.078 \\
\hline & & & & $(0.064)$ & $(0.065)$ \\
\hline \multirow[t]{2}{*}{ HIGHEDU } & & & & -0.272 & -0.272 \\
\hline & & & & $(0.158)$ & $(0.159)$ \\
\hline \multirow[t]{2}{*}{ BMP } & & & & 0.246 & 0.252 \\
\hline & & & & $(0.381)$ & $(0.430)$ \\
\hline \multirow[t]{2}{*}{ EFR } & & & & 0.025 & 0.026 \\
\hline & & & & $(0.112)$ & $(0.108)$ \\
\hline \multirow[t]{2}{*}{ Constant } & $-6.439^{* * *}$ & -5.198 & -4.756 & -4.112 & -4.059 \\
\hline & $(0.184)$ & $(0.215)$ & $(0.111)$ & (3.899) & (4.144) \\
\hline Country fixed effects & No & Yes & Yes & Yes & Yes \\
\hline Year fixed effects & No & No & Yes & Yes & Yes \\
\hline HAC & No & Yes & Yes & Yes & Yes \\
\hline $\mathrm{N}$ & 178 & 178 & 178 & 178 & 178 \\
\hline$P$ (year fixed effects 0 ) & & & 0.0017 & 0.0027 & 0.0034 \\
\hline P (all slopes 0 ) & 0.0000 & 0.0176 & 0.0007 & 0.0000 & 0.0000 \\
\hline $\bar{R}^{2}$ & 0.3795 & 0.0565 & 0.1536 & 0.1663 & 0.1663 \\
\hline
\end{tabular}

Note: All variables are in natural logarithms except the dummies.

HAC refers to heteroscedasticity and autocorrelation consistent standard errors. *** denotes significance at the $1 \%$ level; ** denotes significance at the $5 \%$ level. 
Table 6: The Effect of Intellectual Property Protection (Ginarte-Park Index) Dependent variable - RD

\begin{tabular}{|c|c|c|c|c|c|}
\hline Regressor & (1) & (2) & (3) & (4) & (5) \\
\hline \multirow[t]{2}{*}{ IP-GP } & $2.911^{* * *}$ & $1.651^{* *}$ & -0.373 & 0.017 & 0.067 \\
\hline & $(0.324)$ & $(0.744)$ & $(0.221)$ & $(0.133)$ & $(0.154)$ \\
\hline \multirow[t]{2}{*}{ GDPPC } & & & & -0.060 & -0.235 \\
\hline & & & & $(0.528)$ & $(0.598)$ \\
\hline \multirow[t]{2}{*}{ GP } & & & & $0.932^{* * *}$ & 0.568 \\
\hline & & & & $(0.150)$ & $(0.347)$ \\
\hline \multirow[t]{2}{*}{ SALES } & & & & & 0.437 \\
\hline & & & & & $(0.396)$ \\
\hline \multirow{2}{*}{ SAVINGS } & & & & 0.073 & 0.058 \\
\hline & & & & $(0.057)$ & $(0.059)$ \\
\hline \multirow[t]{2}{*}{ HIGHEDU } & & & & -0.279 & -0.311 \\
\hline & & & & $(0.162)$ & $(0.159)$ \\
\hline \multirow[t]{2}{*}{ BMP } & & & & 0.226 & 0.332 \\
\hline & & & & $(0.399)$ & $(0.449)$ \\
\hline \multirow[t]{2}{*}{ EFR } & & & & 0.018 & 0.033 \\
\hline & & & & $(0.109)$ & $(0.106)$ \\
\hline \multirow[t]{2}{*}{ Constant } & 0.327 & $1.631^{* *}$ & $2.758^{* * *}$ & -4.395 & -4.141 \\
\hline & $(0.364)$ & $(0.770)$ & $(0.173)$ & $(4.037)$ & $(4.175)$ \\
\hline Country fixed effects & No & Yes & Yes & Yes & Yes \\
\hline Year fixed effects & No & No & Yes & Yes & Yes \\
\hline HAC & No & Yes & Yes & Yes & Yes \\
\hline $\mathrm{N}$ & 178 & 178 & 178 & 178 & 178 \\
\hline P (year fixed effects 0 ) & & & 0.0000 & 0.0031 & 0.0031 \\
\hline P (all slopes 0 ) & 0.0000 & 0.0322 & 0.0000 & 0.0000 & 0.0000 \\
\hline $\bar{R}^{2}$ & 0.3102 & 0.1843 & 0.6244 & 0.7283 & 0.7297 \\
\hline
\end{tabular}

Note: All variables are in natural logarithms except the dummies.

HAC refers to heteroscedasticity and autocorrelation consistent standard errors. *** denotes significance at the $1 \%$ level; ** denotes significance at the $5 \%$ level. 
Table 7: The Effect of Intellectual Property Protection - Standardized Coefficients Dependent variable - RDPA

\begin{tabular}{lcccc} 
& \multicolumn{4}{c}{ Treatment Variable } \\
& IP-M & IP-RR & IP-WEF & IP-GP \\
Coefficient & (Table 2, col. 4) & (Table 3, col. 4) & (Table 4, col. 4) & (Table 5, col. 4) \\
SE & -3.452 & 1.684 & 0.104 & 0.040 \\
& $(3.735)$ & $(0.661)$ & $(0.523)$ & $(0.121)$ \\
SD (index of protection) & 0.135 & 0.437 & 0.280 & 0.434 \\
SD (dependent variable) & 1.210 & 1.240 & 1.268 & 1.201 \\
& & & & \\
Standardized Coefficient & -0.385 & 0.594 & 0.023 & 0.014 \\
Standardized SE & $(0.416)$ & $(0.233)$ & $(0.116)$ & $(0.044)$
\end{tabular}

Note: The variables are in natural logarithms

SE denotes 'standard error'

SD denotes 'standard deviation' 
Table 8: The Effect of Intellectual Property Protection (Ginarte-Park Dummy) Dependent variable - RDPA

\begin{tabular}{|c|c|c|c|c|c|}
\hline Regressor & (1) & (2) & (3) & (4) & (5) \\
\hline \multirow[t]{2}{*}{ IP-GPD } & $1.439^{* * *}$ & 0.116 & 0.031 & 0.047 & 0.047 \\
\hline & $(0.144)$ & $(0.358)$ & $(0.268)$ & $(0.257)$ & $(0.256)$ \\
\hline \multirow[t]{2}{*}{ GDPPC } & & & & -0.153 & -0.162 \\
\hline & & & & $(0.458)$ & $(0.558)$ \\
\hline \multirow[t]{2}{*}{ SALES } & & & & & 0.006 \\
\hline & & & & & $(0.162)$ \\
\hline \multirow[t]{2}{*}{ SAVINGS } & & & & 0.081 & 0.081 \\
\hline & & & & $(0.067)$ & $(0.067)$ \\
\hline \multirow[t]{2}{*}{ HIGHEDU } & & & & -0.264 & -0.263 \\
\hline & & & & $(0.165)$ & $(0.170)$ \\
\hline \multirow[t]{2}{*}{ BMP } & & & & 0.243 & 0.245 \\
\hline & & & & $(0.373)$ & $(0.408)$ \\
\hline \multirow[t]{2}{*}{ EFR } & & & & 0.026 & 0.027 \\
\hline & & & & $(0.111)$ & $(0.108)$ \\
\hline \multirow[t]{2}{*}{ Constant } & $-5.394^{* * *}$ & $-4.725^{* * *}$ & $-4.803^{* * *}$ & -4.120 & -4.097 \\
\hline & $(0.103)$ & $(0.181)$ & $(0.142)$ & (3.917) & $(4.115)$ \\
\hline Country fixed effects & No & Yes & Yes & Yes & Yes \\
\hline Year fixed effects & No & No & Yes & Yes & Yes \\
\hline HAC & No & Yes & Yes & Yes & Yes \\
\hline $\mathrm{N}$ & 178 & 178 & 178 & 178 & 178 \\
\hline$P$ (year fixed effects 0 ) & & & 0.0004 & 0.0029 & 0.0032 \\
\hline P (all slopes 0 ) & 0.0000 & 0.7477 & 0.0009 & 0.0000 & 0.0001 \\
\hline $\bar{R}^{2}$ & 0.3573 & 0.0015 & 0.1585 & 0.1664 & 0.1664 \\
\hline
\end{tabular}

Note: All variables are in natural logarithms except the dummies.

HAC refers to heteroscedasticity and autocorrelation consistent standard errors. *** denotes significance at the $1 \%$ level; ** denotes significance at the $5 \%$ level. 
Table 9: The Effect of Contemporaneous vs. Following Period Index of Protection Dependent variable - RDPA

\begin{tabular}{|c|c|c|c|c|c|c|c|c|c|c|}
\hline Regressor & (1) & (2) & (3) & (4) & (5) & (6) & $(7)$ & (8) & (9) & (10) \\
\hline$I P-G P_{t}$ & $\begin{array}{l}1.608^{* * *} \\
(0.163)\end{array}$ & & $\begin{array}{l}0.590^{* * *} \\
(0.102)\end{array}$ & & $\begin{array}{l}0.297^{*} \\
(0.165)\end{array}$ & & $\begin{array}{l}0.242 \\
(0.157)\end{array}$ & & $\begin{array}{l}0.202 \\
(0.129)\end{array}$ & \\
\hline $\mathrm{IP}-\mathrm{GP}_{\mathrm{t}+1}$ & & $\begin{array}{l}1.613^{* * *} \\
(0.189)\end{array}$ & & $\begin{array}{l}0.427^{* *} \\
(0.179)\end{array}$ & & $\begin{array}{l}0.156 \\
(0.277)\end{array}$ & & $\begin{array}{l}0.170 \\
(0.267)\end{array}$ & & $\begin{array}{l}0.123 \\
(0.241)\end{array}$ \\
\hline Controls (BS) & No & No & No & No & No & No & Yes & Yes & No & No \\
\hline Controls (AS) & No & No & No & No & No & No & No & No & Yes & Yes \\
\hline Country fixed effects & No & No & Yes & Yes & Yes & Yes & Yes & Yes & Yes & Yes \\
\hline Year fixed effects & No & No & No & No & Yes & Yes & Yes & Yes & Yes & Yes \\
\hline HAC & No & No & Yes & Yes & Yes & Yes & Yes & Yes & Yes & Yes \\
\hline $\mathrm{N}$ & 108 & 108 & 108 & 108 & 108 & 108 & 108 & 108 & 108 & 108 \\
\hline$P$ (year fixed effects 0 ) & & & & & 0.0252 & 0.0068 & 0.0208 & 0.0112 & 0.0028 & 0.0024 \\
\hline P (all slopes 0$)$ & 0.0000 & 0.0000 & 0.0000 & 0.0246 & 0.0000 & 0.0017 & 0.0000 & 0.0001 & 0.0000 & 0.0001 \\
\hline $\bar{R}^{2}$ & 0.4724 & 0.4015 & 0.0823 & 0.0608 & 0.1286 & 0.1178 & 0.1323 & 0.1287 & 0.1272 & 0.1237 \\
\hline
\end{tabular}

Note: All variables are in natural logarithms except the dummies.

$* * *$ denotes significance at the $1 \%$ level; ** denotes significance at the $5 \%$ level.

Controls (BS) refers to the 'base specification' controls

Controls (AS) refers to 'alternative specification' controls (i.e. including SALES)

HAC refers to heteroscedasticity and autocorrelation consistent standard errors

RMSE denotes 'root mean squared error' 
Table 10: The Effect of Contemporaneous vs. Following Period Index of Protection Dependent variable - RDPA

$\begin{array}{llllll}\text { Regressor } & (1) & (2) & (3) & (4) & (5) \\ \text { IP-GP }_{\mathrm{t}} & 0.790^{* * *} & 0.447^{* *} & 0.270 & 0.198 & 0.176 \\ & (0.241) & (0.175) & (0.173) & (0.142) & (0.137) \\ \text { IP-GP }_{\mathrm{t}+1} & 0.310 & 0.231 & 0.064 & 0.108 & 0.077 \\ & (0.222) & (0.226) & (0.281) & (0.273) & (0.254) \\ & & & & & \\ \text { Controls (BS) } & \text { No } & \text { No } & \text { No } & \text { Yes } & \text { No } \\ \text { Controls (AS) } & \text { No } & \text { No } & \text { No } & \text { No } & \text { Yes } \\ \text { Country fixed effects } & \text { No } & \text { Yes } & \text { Yes } & \text { Yes } & \text { Yes } \\ \text { Year fixed effects } & \text { No } & \text { No } & \text { Yes } & \text { Yes } & \text { Yes } \\ \text { HAC } & \text { No } & \text { Yes } & \text { Yes } & \text { Yes } & \text { Yes } \\ \text { N } & 108 & 108 & 108 & 108 & 108 \\ \text { P (year fixed effects 0) } & & & 0.0412 & 0.0213 & 0.0029 \\ \text { P (all slopes 0) } & 0.0000 & 0.0000 & 0.0001 & 0.0000 & 0.0000 \\ \bar{R}^{2} & 0.0864 & 0.0869 & 0.1209 & 0.1257 & 0.1193\end{array}$

Note: All variables are in natural logarithms except the dummies. $* * *$ denotes significance at the $1 \%$ level; ** denotes significance at the $5 \%$ level. Controls (BS) refers to the 'base specification' controls Controls (AS) refers to ‘alternative specification’ controls (i.e. including SALES) HAC refers to heteroscedasticity and autocorrelation consistent standard errors 
Figure 1: Scatterplots of R\&D Performed by Affiliates (RDPA) on the indices of protection

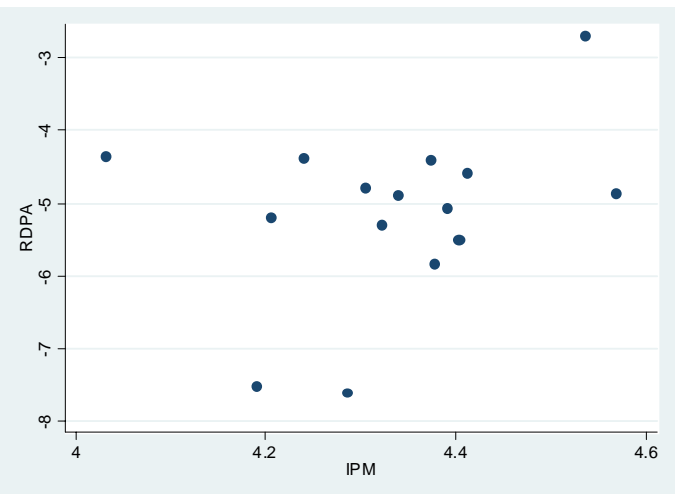

(a)

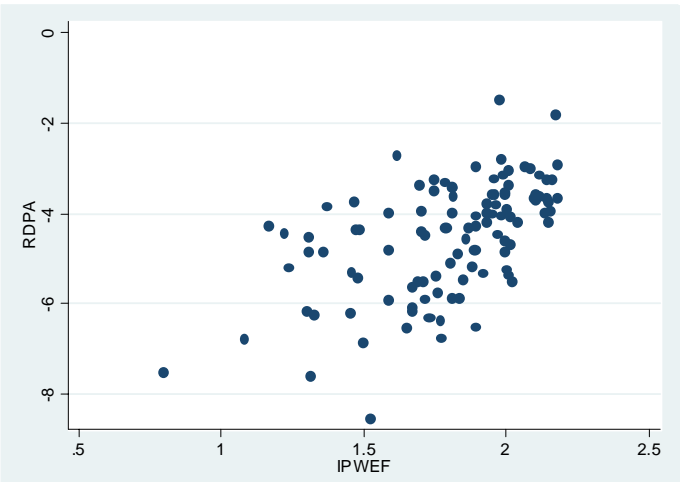

(c)

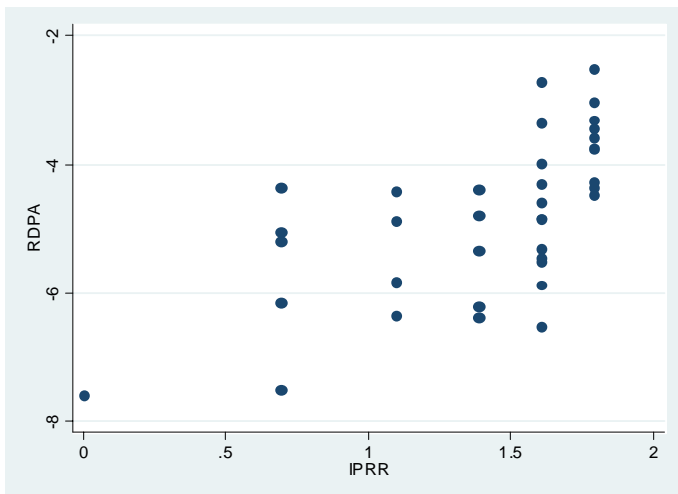

(b)

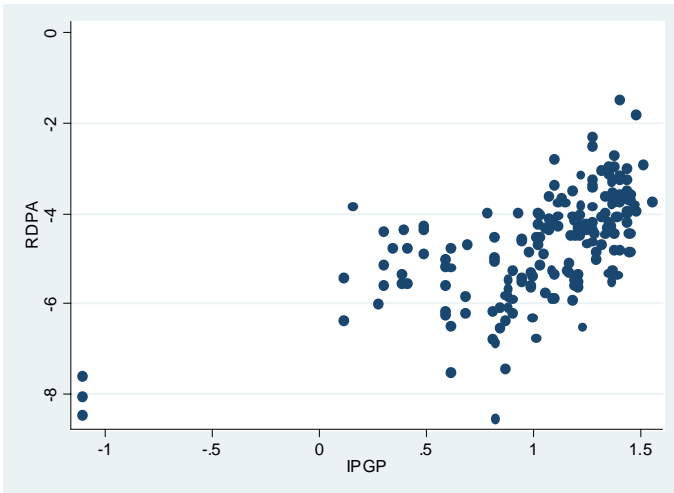

(d)

Note: The variables are in (natural) logarithms. 


\section{Endnotes}

1 Strictly speaking, innovation has to do with the technology in existence whereas technological change has to do with the technology actually in use, but at the practical level this distinction does not help.

2 Some studies (see, for example, Davis 2004) aver that the 'original' objective of protection (to encourage innovation) has given way over time to other objectives (such as facilitation of strategic license-swaps), appearing to imply the diminishing influence of intellectual property protection in encouraging innovation. Similarly, Scotchmer (2004) adduces evidence to support the view that such protection probably ranks fairly low down the list of alternative means of protecting innovation. These studies miss the point that even if the innovation-inducing role of protection may have been overshadowed by other roles, or indeed such protection may not necessarily be the most important form of protecting innovations, one can still legitimately ask the question whether stronger protection (still) induces more innovation.

${ }^{3}$ A related but different question has to do with the distribution of the rents accruing from higher minimum protection, as under the TRIPs agreement. McCalman (2005, 2001) shows that although the distribution of these benefits is likely to be skewed in favour of the developed countries, there is potential for all countries to benefit from this stronger protection.

4 There's a substantial body of literature which studies the overseas r\&d activities of firms, but does not consider how that r\&d varies between countries in response to their 
strengths of intellectual property protection. For a useful survey see Granstrand, Hakanson and Sjolander (1993).

${ }^{5}$ If we restrict ourselves to their equations (1) and (4) (Table IV, p. 340), the protection dummy is insignificant in (4) and barely significant in (1). For the other four equations, they report that the positive effect of stronger protection is particularly true for firms which have high patent use - but this is a statement that the protection variable was relatively stronger for the high-patent-use firms than for the low-patent-use firms; it does not show that the effect of stronger protection per se was significant for either group of firms. The level of protection variable, as we have noted, was insignificant in five of the six regressions.

${ }^{6}$ The data available do not pertain to the overseas activity of each affiliate in a given country, but only to the sum total of affiliates in a given country. For further details see the data section below.

${ }^{7}$ We are grateful to Walter Park for making the post-1990 values of their index of protection available to us.

${ }^{8}$ Barring Taiwan, which acceded to the WTO in 2002. Note that Taiwan is not included in the sample of countries that we use with the IP-GP index, because values of this index are not available for Taiwan.

${ }^{9}$ In principle at least, a similar argument could be made about membership of trade agreements as well. For instance, a case may be made out that Mexico would have to tighten its intellectual property laws courtesy its membership of the North American Free Trade Agreement; therefore, one should consider membership of such agreements as well, in manifesting the strength of protection a country provides. There are several 
practical problems with this argument, however. It is not clear which trade agreements have such an effect and which ones don't. It is not clear either, to what extent trade agreements have such an effect, assuming they do. Further, is this effect stronger for a country that is party to seven trade agreements as compared to one that is party to only six trade agreements? Given that most (if not all) countries in our sample are party to several bilateral and regional trade agreements, one would not expect much variation in this factor anyway. Consequently, we do not fret about this aspect.

${ }^{10}$ Of course, it is quite possible that a particular location may be used to serve not just that (local) market, but other markets as well; in which case, the size of that local market may not be the determining factor. It would be possible to avoid this slippage only if one had access to detailed information on the exact market jurisdictions of each 'hub'. Given the paucity of such data, we have to rest content with less ideal proxies.

${ }^{11}$ Ideally one would also like to account for any other taxes such as withholding taxes on company profits. Such data, however, are not available.

${ }^{12}$ Final estimates of the benchmark survey data for 2004 are not yet available.

${ }^{13}$ Data on IP-WEF are also available for some years after 1999, but that does not help us because r\&d data are not available beyond the 1999 BEA survey (as we noted in the previous note).

${ }^{14}$ In constructing the black market premium variable, magnitudes of the ratio larger than three were restricted to equal three. This was mostly true for a very small number of values for Argentina and Brazil (corresponding to periods of runaway inflation in those countries), and did not affect the estimation results in any way. 
${ }^{15}$ Actually data on the Mansfield index of protection were available for 16 countries; however, there was no overseas r\&d investment by US firms in this 'sixteenth' country (Nigeria), and so it was not included in the sample.

${ }^{16}$ We lumped together the Asian and African categories because there is only one African country in this sample.

${ }^{17}$ The adjective 'region' is not quite true for these dummy variables, and we use it only for convenience.

${ }^{18}$ These results are superficially comparable with those furnished by Kumar (1996), as regards the significance of the index of protection. Kumar, however, does not correct for autocorrelation. Also, although he uses panel data, he does not specify how he treats the index of protection variable over time, given that his index (the Rapp-Rozek measure) is available for only one year. He does note, that this index is subjective and "has its own limitations", and "the inferences drawn ... should be treated with caution". Of course, regarding his study, we take exception not just to the subjective nature of this index, but also with the lack of correction for cross-country variations in various fixed factors. Doing this, as we show below, leads to a different conclusion about the influence of the strength of protection on overseas $r \& d$ as a mode of technology transfer

${ }^{19}$ We may also note in passing, that when we re-did the estimation exercises reported in the previous three sections for $I P-M, I P-R R$ and $I P-W E F$, using $R D$ as the dependent variable, the results were essentially the same as what we found using RDPA as the regressand.

${ }^{20}$ The median levels of the index of protection IP-GP corresponding to the survey years 1977, 1982, 1989, 1994 and 1999 were 2.80, 2.99, 2.95, 3.41 and 4.00, respectively. 
${ }^{21}$ The well-known textbook example of 'weather' being an 'ideal' instrumental variable for identifying an agricultural demand curve is a case in point (see Stock and Watson, 2007). The authors claim that rainfall does not have a direct influence on demand and, therefore, satisfies the condition of instrument exogeneity. Rainfall would affect not just a farmer's supply, however, but also his demand, insofar as his income depends on what he sells. If one is considering the rural economy only, or if one is considering a situation where the rural economy dominates the economy as a whole, then rainfall does not necessarily satisfy the condition of instrument exogeneity. 